${ }^{\circ}$ Entomologica Fennica. 5 December 1995

\title{
A comparison of pitfall trapping and quadrat sampling of Carabidae (Coleoptera) on river banks
}

\author{
Johan Andersen
}

\begin{abstract}
Andersen, J. 1995: A comparison of pitfall trapping and quadrat sampling of Carabidae (Coleoptera) on river banks. - Entomol. Fennica 6:65-77.

A comparison was made between the "open"pitfall trap method and quadrat sample method in microhabitats on river banks. The latter method was found to give reliable estimates of the absolute abundance of carabid beetle species. In pitfall traps individuals of the carabid beetle Bembidion schuppelii were over-represented in a sub-optimal microhabitat compared with in optimal ones. The niche-overlap between this species and B. bipunctatum was 0.19 in quadrat samples and 0.59 in pitfall traps. There was no correlation between the relative abundance of individuals of species in quadrat samples and in pitfall traps. Individuals of larger carabid species were highly over-represented compared to smaller ones in pitfall traps, an effect that was independent of diurnal rhythm and life cycle category. Biomass of larger carabid species was also overestimated in pitfall traps compared to that of smaller ones. Imagines were more efficiently captured in pitfall traps than larvae. Pitfall traps had a higher number of species than quadrat samples in all investigated sites. In four of five cases the Shannon-Wiener index gave higher species diversity in pitfall traps than in quadrat samples. It is concluded that the "open"pitfall trap method is inappropriate to study dominance ratio, the ecological role of species and perhaps the species diversity within communities. The general insight into the community structure of carabid beetles may therefore be very biased
\end{abstract}

Johan Andersen, Institute of Biology and Geology, University of Troms $\phi$, N-9037 Troms $\phi$, Norway

\section{Introduction}

Pitfall trapping is the most widely used sampling method in ecological field studies of carabid beetles (Thiele 1977). The method has been used in various types of studies: 1) Faunistic surveys; 2) Population estimation by marking/-release/recapture (e.g. Greenslade 1964 b, Schjötz-Christensen 1965); 3) diel activity pattern (references in Thiele $1977)$; 4) seasonal activity and reproductive period (e.g. Greenslade 1965; Schjötz-Christensen
1965, Murdoch 1967; Refseth 1980); 5) population changes between years (e.g. Baars 1979); 6) habitat selection of species (e.g. Greenslade 1963, Baars 1979, Luff 1982) and 7) dominance and species diversity within communities (e.g. Bengtson 1980, DenBoer 1980, Andersen 1982, Thingstad 1987, Nilsson 1987, Bauer 1989, Hejkal 1990, see also references in Thiele 1977).

There has been much controversy as to the adequacy of the method. The catches seem to depend, among other things, on such factors as 
trap type, trap size, material in the roof, type of collecting fluid, the number of traps, the distance between, and the arrangement of traps, and the time elapsed between the emptying of the traps (Luff 1967, 1975, Thiele 1977, Adis 1979, Holopainen 1990, Spence \& Niemelä 1994).

An expression of activity density of species is the most serious problem with the pitfall trap method (Thiele 1977). The activity density is determined both by abundance and activity or "Aktionsradius"(Kuschka et. al. 1987) of the individuals. This seems to make minor or no problems in studies of type 1), 2), 3) but the opinion about the adequacy of the method when used to study habitat selection of species (6) and community structure (7) is contradictory (e.g. Briggs 1960, Bombosch 1962, Greenslade 1964 a, Baars 1979, Luff 1982, Niemelä et.al. 1990, Spence \& Niemelä 1994). Although pitfall traps have been used extensively in ecological field studies of carabid beetles, few studies have made direct comparisons between this method and absolute quantitative methods such as quadrat sampling.

The present work compares results of pitfall trapping and quadrat sampling of carabid beetles on river banks and adresses the following questions:

1. Do the catches in traps reliably reflect the relative abundance of a carabid beetle species in different habitats?
2. How do the catches in traps reflect the real dominance ratio (relative abundance) and energetic importance of various species of Carabidae within a community (habitat) ? Does size of species and diel activity pattern influence catches?

Only "open"trap systems are considered here, i.e. traps not surrounded by a fence. The use of pitfall traps in connection with marking/release/ recapture is not dealt with in this study.

Baars (1979) recommends that pitfall traps should be used for an extended period to give reliable results, e.g. about relative abundance in different habitats. This is difficult to accomplish on river banks due to a fluctuating water level. However, if the traps are used during a period with stable water level and within the period during which the species show their highest activity, i.e. usually in their reproduction period (Murdoch 1967), it is likely that the catches give reliable estimates of the activity density (vide also Niemelä et.al. 1990). A majority of the river bank species are spring breeders which reproduce and have their main activity period in MayJune ( $\mathrm{S}$ and Central Norway) or in June-July (Northern Norway). Another group of species (autumn breeders) reproduce and have their main activity in July-August in S and Central Norway (Lindroth 1945, 1985-86, Andersen 1970, 1983 b, Refseth 1986, 1988). Investigations were there-

Table 1. Information concerning quadrat sampling and pitfall trapping in the areas investigated. Distance between the traps was always two meters. Size of quadrats was 0.250 in locality $1,0.125$ in all other localities; diameter of the pitfall trap opening was $7.5 \mathrm{~cm}$ in locality $1,7.0 \mathrm{~cm}$ in all others.

\begin{tabular}{llcllc}
\hline $\begin{array}{l}\text { Locality and } \\
\text { microhabitat }\end{array}$ & $\begin{array}{l}\text { Number of: } \\
\text { quadrats }\end{array}$ & traps & \multicolumn{2}{l}{ Time of sampling } \\
& & & & quadrats & traps \\
\hline $1(2 a)$ & 10 & 5 & 1973 & $5.8 \& 13.8$ & $5.8-13.8$ \\
$2(3 a)$ & 10 & 9 & 1988 & $9.7 \& 17.7$ & $9.7-16.7$ \\
$2(3 a)$ & 6 & 5 & 1990 & 6.7 & $3.7-6.7$ \\
$2(4 a$ moss) & 20 & 12 & 1988 & $9.7 \& 17.7$ & $9.7-16.7$ \\
$2(4 a$ Carex) & 16 & 10 & 1988 & $9.7 \& 17.7$ & $9.7-6.7$ \\
$2(4 b)$ & 10 & 9 & 1988 & $9.7 \& 17.7$ & $9.7-16.7$
\end{tabular}

Microhabitat 3a: Under trees, silty medium moist substratum, vegetation coverage 4-5. 4a moss: Open spots, silty substratum saturated with water, dense moss of the family Amblystegiaceae. 4a Carex: As the previous microhabitat, but vegetation consists of dense, high Carex aquatilis. $4 \mathrm{~b}$ : open, elevated sites, dry - medium moist, fine sand, vegetation of Festuca ovina, Trifolium repens and Calamagrostis stricta, coverage 1-3. 
fore done in July in Northern Norway (to estimate activity density and absolute abundance of spring breeders) and in August in Central Norway (to estimate activity density and absolute abundance of autumn breeders).

\section{Material and methods}

Quadrat sampling and pitfall trapping were compared at two different localities:

1) Melhus, Sør-Trøndelag county, Central Norway. At the bank of the river Gaula. The sampling area was situated in a forest with rather dense herbaceous vegetation of Poa sp. and Calamagrostis stricta (microhabitat 2a, vide Andersen 1970, 1983a).

2). Gullhav, Målselv, Troms county, N. Norway. At the bank of river Målselva. Four different microhabitats, described in Table 1, were selected. A more detailed description is given in Andersen (1970, 1983a).

Information concerning the two sampling methods are shown in Table 1. The pitfall traps, which were filled with $2 \%$ formalin solution were, whenever possible, placed in rows within each microhabitat. Quadrat samples were taken mid between the position of the traps. In the quadrat samples all vegetation and impediments were removed where- after water was poured over the sites.

Beetles were picked by hand within a 5 min period. Most beetles within a quadrat are collected by this procedure (Basedow et.al. 1988). Some additional beetles were collected by removing the uppermost $5 \mathrm{~cm}$ of the soil layer whereafter it was thoroughly washed in a bucket filled with water. Quadrat sampling was done 12-24 hours before and/or after the pitfall traps were in function. The results indicate that this procedure minimizes biases due to disturbance of beetles. Quadrat samples were taken by day as well as by night in locality 2 , but there was no apparent differences between diurnal and nocturnal catches.

Females of most of the species of the imaginal hibernators occuring at locality 2 were dissected to examine the development of the ovaries.

Size of beetles is based on the median length of the species as given in Lindroth (1985-86). Biomass figures are based on dry weight of beetles.

Pooled catches from pitfall trapping from each microhabitat were compared with corresponding catches from quadrat sampling by means of Spearman's rank correlation (Siegel 1956). In all cases where chi-square tests were done, expected values were 3 or above. By calculation of confidence limits, a logarithmic transformation was used when the number of samples was $<30$ and a chisquare test of variance to mean ratio indicated a contagious distribution. Niche overlap was calculated by means of the formula of Pianka (1975) whereas the Shannon-Wiener index was used to calculate species diversity as follows:

Table 2. Spearman's rank correlation coefficients $\left(r_{s}\right)$ for pitfall and quadrat catches based on total catches $(T)$, catches of spring breeders (I) or autumn breeders (II), and total number of individuals and biomass (in brackets) of Carabid beetles in pitfall traps $(P)$ and quadrat samples $(Q)$ in relation to dial activity pattern (N: nocturnal, D: Diurnal) and size (S: small, L: large). The $\chi^{2}$-tests concern differences in ratio of individuals. Results for individual species are shown in Appendix 1 and 2.

\begin{tabular}{|c|c|c|c|c|c|c|c|c|}
\hline $\begin{array}{l}\text { Locality, } \\
\text { microhabitat } \\
\text { (in brackets) }\end{array}$ & T & I & II & Categon & P & $\mathrm{Q}$ & $x^{2}$ & $p$ \\
\hline \multirow[t]{5}{*}{$1(2 a)$} & $0.70 ; n s$ & & $0.30 ; n s$ & & & & & \\
\hline & & & & $\mathrm{N}, \mathrm{II}$ & 277 & 13 & 23.4 & $<0.001$ \\
\hline & & & & $\mathrm{D}, \mathrm{II}$ & 44 & 14 & & \\
\hline & & & & $\mathrm{N}, \mathrm{II}, \mathrm{L}^{\star}$ & $207(3100)$ & $1(15)$ & & \\
\hline & & & & $\mathrm{N}, \mathrm{Il}, \mathrm{S}^{*}$ & $70(419)$ & $12(32)$ & 24.3 & $<0.001$ \\
\hline \multirow[t]{7}{*}{2 (3a, July 199} & $00.24 ; \mathrm{ns}$ & 0.16 ; ns & & & & & & \\
\hline & & & & $\mathrm{N}, \mathrm{I}$ & 13 & 0 & 6.5 & $<0.05$ \\
\hline & & & & $D, I$ & 48 & 33 & & \\
\hline & & & & $\mathrm{I}, \mathrm{L}$ & 29 & 3 & & \\
\hline & & & & $\mathrm{I}, \mathrm{S}$ & 32 & 30 & 12.5 & $<0.001$ \\
\hline & & & & $\mathrm{D}, \mathrm{I}, \mathrm{L}^{\star *}$ & $16(89)$ & $3(25)$ & & \\
\hline & & & & $\mathrm{D}, \mathrm{I}, \mathrm{S}^{\star *}$ & $32(23)$ & $30(17)$ & 5.1 & $<0.05$ \\
\hline
\end{tabular}

ns: not significant $(p>0.05) ; ~ *:$ 3.8-8.7 and 10.2-11.3 mm, respectively; ${ }^{* *}: 3.0-4.6$ and $6.0-8.9$ mm, respectively. 

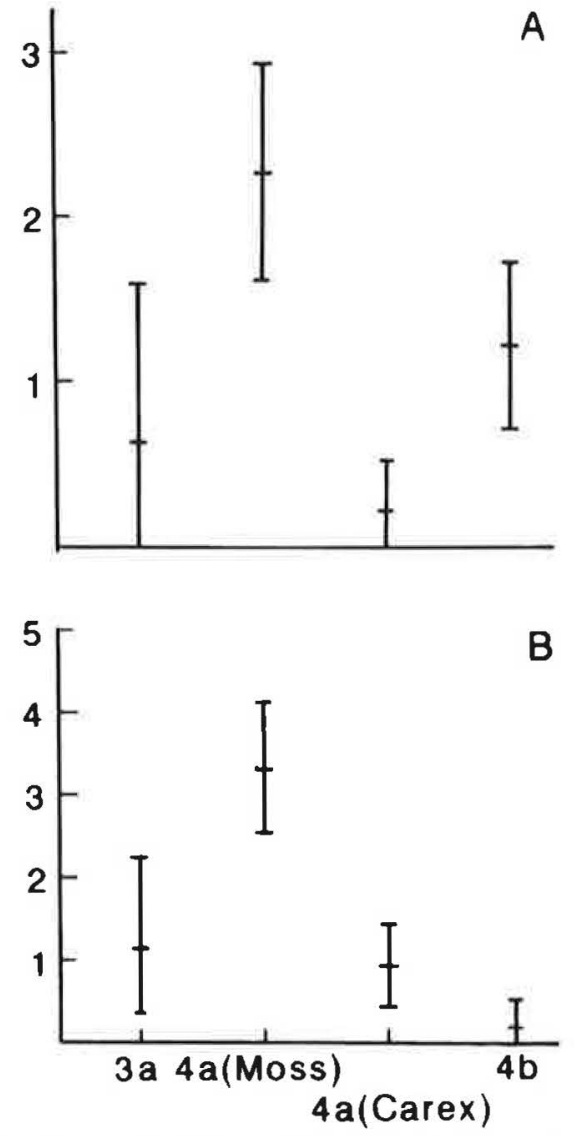

Fig. 1. Mean with $95 \%$ confidence limits of number of individuals of $B$. schuppelii per trap and day $(A)$ and per quadrat $(B)$ in four microhabitats at locality 2 in July 1988.

$$
\mathrm{H}=-\sum \mathrm{s}_{\mathrm{i}=1}(\mathrm{pi}) \text { (lnpi) }
$$

where pi is the proportion for the $\mathrm{i}$ th species and $\mathrm{s}$ is the total number of species found in the community. The evenness component (E) which measures the evenness of allotment of individuals between the species on an ascending scale 0-1 (Dennison \& Hodkinson 1984) was calculated as follow:

$$
\mathrm{E}=\mathrm{H} / \mathrm{H} \max
$$

where $H$ is the observed Shannon-Wiener function and Hmax the value of the diversity function when all $s$ species are equally abundant.

The nomenclature of carabid beetles is according to Lindroth (1985-86).

\section{Results}

The water level in the river was stable and low during the catching period at locality 1 . The same applied to locality 2 in 1988 indicated by the fact that microhabitat 4 a moss and $4 \mathrm{a}$ Carex kept close to the river during the whole catching period. In 1990 the water level at locality 2 fluctuated much more and one row of traps placed close to the river was submerged. The results from these traps were therefore omitted.

There was no significant correlation between the relative frequency (dominance ratio) of the carabid beetle species in pitfall traps and in quadrat samples in the microhabitats (Table 2 and 3, Appendix 1-3).

Individuals of $B$. schuppelii were over-represented in pitfall traps in microhabitat $4 \mathrm{~b}$ relative to in 4a moss (Fig. 1). The niche-overlap in the microhabitat dimension between $B$. schuppelii and $B$. bipunctatum at locality 2 in 1988 was 0.19 in quadrat samples whereas it was 0.59 in pitfall traps.

At least at locality 1 the carabid beetle fauna consisted of diurnal, as well as nocturnal, and small as well as larger, species (Appendix 1 and 2). The ratio of individuals of nocturnal to diurnal species was higher in pitfall traps than in quadrat samples. Furthermore, there was a clear over-representation of individuals of larger species in pitfall traps relative to in quadrat samples (Table 2 and 3). This applies to both diurnal and nocturnal species. The same trend was found on a biomass scale (Table 2 and 3). Imagines of Carabidae were more efficiently captured in pitfall traps than larvae (Table 4).

The number of species (S) collected was higher in pitfall traps than in quadrat samples in all the microhabitats investigated (Table 5, Appendix 1-3). The Shannon-Wiener index $(\mathrm{H})$ gave higher species diversity in pitfall traps than in quadrat samples in four of five cases. The same applied to the evenness component (E) (Table 5).

\section{Discussion}

The quadrat sampling method as conducted here is supposed to be an adequate method to determine the absolute abundance of imagines. The larvae, however, partly sink by washing (Andersen 1968) and they are therefore underrepresented relative to their real absolute density. Bias between quadrat sampling and pitfall trapping due, for example, to 
disturbance of beetles or differences in spatial distribution between day and night are supposed to be small (Material and methods).

Although a majority of the carabid species are carnivores/-scavengers some groups (e.g. Amara spp., Harpalus spp., Bradycellus spp.) are partly phytophagous (Lindroth 1949, 1985-86, Johnson \& Cameron 1969, Thiele 1977, Zetto Brandmayr \& Brandmayr 1978, Forsythe 1982). There is a possibility that such differences in food selection influence pitfall trap catches for instance by less trapability of phyto-phagous species. Such possible bias does not apply to river banks, however, since all the species living there seem to be carnivores/scavengers (Lindroth 1949, 1985-86, Davies 1953,
Hengeveld 1980, Andersen 1987).

At locality 1) Melhus, nearly all the collected individuals belonged to autumn-breeding species (Appendix 1). Among these species Trechus secalis and Patrobus atrorufus are most active in JulyAugust, whereas Nebria rufescens has its peak activity somewhat earlier (Refseth 1986, 1988). It is possible, therefore, that the bias in the pitfall trap results would have been still greater if the traps had been used for a more extended period.

The spring breeding species at locality 2 (Appendix 2 and 3 ) have their breeding and activity period at the same time (Lindroth 1945, Andersen 1970, 1983b, Appendix 4). rs for this group (Table 2 and 3 ) is therefore supposed to be repre-

Table 3. Spearman's rank correlation coefficients $\left(r_{S}\right)$ for pitfall and quadrat catches based on total catches (T) and catches of spring breeders (I) [A], and total number of individuals and biomass (in brackets) of crabid beetles in pitfall traps and quadrat samples in relation to diel activity pattern and size in four microhabitats at locality 2), July 1988 [B]. For further explanation see Table 2. Results for individual species are shown in Appendix 3. None of the correlations in part A are significant.

\begin{tabular}{lllll}
\hline A & & & \\
Microhabitat & 3a & 4a moss & 4a Carex & 4b \\
\hline$T$ & 0.23 & 0.35 & -0.30 & 0.54 \\
1 & 0.11 & 0.40 & -0.18 & 0.51 \\
\hline
\end{tabular}

\section{B}

\begin{tabular}{|c|c|c|c|c|c|c|c|c|}
\hline \multirow[t]{2}{*}{ Microhabitat } & \multicolumn{2}{|l|}{$3 a$} & \multicolumn{6}{|c|}{ 4a moss } \\
\hline & $P$ & $Q$ & $x^{2}$ & $p$ & $\mathrm{P}$ & $Q$ & $\chi^{2}$ & $p$ \\
\hline N.I & 11 & 0 & 3.9 & $<0.05$ & 3 & 1 & & \\
\hline D.I & 29 & 16 & & & 82 & 74 & & \\
\hline $1, L^{*}$ & 26 & 0 & 16.9 & $<0.001$ & 22 & 3 & 12.9 & $<0.001$ \\
\hline $1 . S^{\star *}$ & 14 & 16 & & & 63 & 72 & & \\
\hline D.I.L." & $15(132)$ & $O(0)$ & 10.2 & $<0.01$ & $19(160)$ & $2(22)$ & & \\
\hline D.I.S & $14(8)$ & $16(8)$ & & & $63(53)$ & $72(40)$ & 12.3 & $<0.001$ \\
\hline \multirow[t]{2}{*}{ Microhabitat } & \multicolumn{2}{|c|}{ 4a Carex } & & & \multicolumn{2}{|l|}{$4 b$} & & \\
\hline & $\mathrm{P}$ & Q & $\chi^{2}$ & $p$ & $\mathrm{P}$ & $\mathrm{Q}$ & $\chi^{2}$ & $\mathrm{p}$ \\
\hline N.I & 348 & 0 & & & 48 & 20 & 5.6 & $<0.05$ \\
\hline D.I & 9 & 21 & & & 143 & 123 & & \\
\hline$I . L^{*}$ & 354 & 1 & & & 68 & 0 & 10.0 & $<0.01$ \\
\hline$I . S^{\star *}$ & 3 & 22 & & & 122 & 22 & & \\
\hline D.I.L. & $6(38)$ & $0(0)$ & & & $20(48)$ & $0(0)$ & 5.8 & $<0.05$ \\
\hline D.I.S ${ }^{* *}$ & $3(3)$ & $21(14)$ & & & $123(130)$ & $22(27)$ & & \\
\hline
\end{tabular}

${ }^{*}=6.0-10.8 ;{ }^{* \star}=3.0-5.2$ 
sentative. There is some uncertainty, however, as to the ratio NI/DI for locality 2 (Table 2 and 3) since the diel activity pattern of some species may change from nocturnality to diurnality with increasing latitude (Erikstad 1989) (see Appen$\operatorname{dix} 2$ ).

There is a significant over-representation of individuals of the larger imaginal hibernators in pitfall traps at locality 2 independent of a possible shift from nocturnality to diurnality of Pelophila borealis and Agonum fuliginosum (Appendix 2 and 3) since both the ratio D,I,L/D,I,S and I,L/I,S gave significant differences in the yields by the two methods.

Imagines were generally more efficiently captured in pitfall traps than larvae (Table 4). The reason for this is probably that the larvae move in crevices in the earth to a larger extent than imagines which move more along the surface.

Activity and strata dwelling may therefore be far more important than density in determining the yield of species in traps. These results as well as those of Dennison \& Hodkinson (1984), Desender \& Maelfait (1986) and Spence \& Niemelä (1994) indicate that pitfall trap catches give inadequate information about the real dominance ratio of species within communitics.

Baars (1979) found positive correlation between mean density (quadrat samples) and number of individuals in pitfall traps of two carabid beetle species collected in different years and in different habitats. On the other hand, pitfall trap catches of $B$. schuppelii on river banks suggest that a species may be over-represented in sub-optimal microhabitats (Fig. 1, see also Andersen 1970, 1983 a for microhabitat preference). This is in accord- ance with Grüm (1971) who found that the activity of satiated individuals of carabid beetles was higher in sub-optimal than in optimal habitats. Bombosch (1962) found no correlation between trap catches and the catches per unit area of the curculionid beetle Sitonia lineatus in different habitats. Based on my own results as well as those of Bombosch (1962) and Grüm (1971) I conclude, therefore, that it is uncertain how adequately pitfall trap catches express the relative density of a species in different habitats (see also Greenslade 1964b).

Studies of habitat overlap of species using pitfall traps were done by e.g. Bengtson (1980), Thingstad (1987), Erikstad et. al. (1989) and Kegel (1990). The present study indicates that the open pitfall trap system may be less useful to study resource overlap between species in the habitat dimension. Thus, the overlap between Bembidion schuppelii and $B$. bipunctatum was much larger in pitfall traps than in quadrat samples. The explanation is probably as follows: since species may be over-represented in pitfall traps in sub-optimal habitats, the method may mask differences in the real abundance of spe-

Table 4. Comparison of catches of imagines and larvae of Carabidae in pitfall traps $(P)$ and quadrat samples $(Q)$ in microhabitat 4 a moss at locality 2 , July 1988.

\begin{tabular}{lrrr}
\hline & $P$ & & $Q$ \\
\hline Imagines & 86 & & 75 \\
Larvae & 1 & 13.0 & 17 \\
$\chi^{2}$ & & $<0.001$ & \\
$P$ & & & \\
\hline
\end{tabular}

Table 5. Number of species (S), the Shannon-Wiener index $(H)$ and the eveness component $(E)$ in pitfall traps $(P)$ and quadrat samples $(Q)$ at the localities investigated. $H=-\Sigma S_{i=1}$ (pi) (Inpi) where $p_{1}$ is the proportion for the ith species and $\mathrm{s}$ is the total number of species found in the community. $\mathrm{E}=\mathrm{H}_{\text {max }}^{\mathrm{H}}$ where $\mathrm{H}$ is the observed ShannonWiener function and $\mathrm{H}_{\max }$ is the value of the diversity function when all $\mathrm{S}$ species are equally abundant.

\begin{tabular}{lllllllll}
\hline $\begin{array}{l}\text { Locality, } \\
\text { Year }\end{array}$ & Microhabitat & P & Q & P & Q & P & E \\
\hline 1 & 2a & 7 & 4 & 1.14 & 1.02 & 1.14 & 1.02 \\
2,1988 & 4a moss & 7 & 6 & 1.51 & 0.54 & 0.78 & 0.30 \\
$-"$ " & 4a Carex & 7 & 4 & 0.28 & 0.90 & 0.14 & 0.65 \\
2,1990 & 4b & 7 & 2 & 1.16 & 0.31 & 0.59 & 0.44 \\
\hline
\end{tabular}


cies in different microhabitats and hence lead to an overestimation of overlap between species. It is, perhaps, only possible to make valid conclusions in those cases where overlap between species in the traps from different habitats is low or nil.

Desender \& Maelfait (1986) found that diurnal species were more active than nocturnal ones in a grazed pasture and that the ratio of the former was higher in pitfall traps than in quadrat samples. However, the present results were, in part, the reverse, e.g. at locality 1 (Tables $2-3$ ). At least at locality 1 the species are supposed to have the diel activity pattern given in Appendix 1. Greenslade (1964a) also found an under-representation of diurnal species in pitfall trap catches from arable land. It is, therefore, impossible to draw any general conclusions about a connection between the diel activity pattern and the trapability of carabid beetles.

The ratio of individuals of larger to smaller species is higher in pitfall traps than in quadrat samples independent of diel activity pattern (Tables 2-3). Spence \& Niemelä (1994) got similar results and they discuss mechanisms behind the pattern. One of these mechanisms is activity. It is likely that the larger species are more active than the smaller ones, although they do not always have the highest speed of locomotion (Mossakowski \& Stier 1981). Halsall \& Wratten (1988) found that trap capture rates were unrelated to beetle size, speed of movement and diurnal activity, whereas Morill et. al. (1990) found that beetles which moved rapidly were more likely to be captured. Halsall \& Wratten (1988) conducted laboratory experiments and it is questionable whether their results are applicable to natural situations.

There is some disagreement about the relation between abundance and size of species, but according to Griffiths (1992) much of this results from using an inappropriate method of analysis. Within taxonomically related organisms maximum density often occurs in species of intermediate body size whereas the largest species always have low abundances (Morse et.al., 1988, Blackburn et.al., 1990, Griffiths, 1992, Currie 1993). The present and other investigations where absolute quantitative methods have been employd (e.g. Schjötz-Christensen 1957, Heydemann
1962, Frank 1971, Dennison \& Hodkinson 1984, Sekulic et.al. 1987, Gruttke \& Weigmann 1990, Garry 1993, Spence \& Niemelä 1994) also indicate that larger species usually have smaller population density than most smaller species (cf. also Thiele 1977).

Contrary to this, individuals of large, carnivorous species (Carabus spp., Abax spp, the largest Pterostichus spp.; median length $>15$ $\mathrm{mm}$ ) are the most or among the most frequently encountered carabid beetles in numerous investigations where pitfall traps have been used. This applies both to woodland and open habitats, e.g. arable land (Tischler 1958, Lücke 1960, Scherney 1960, Greenslade 1963, Heydemann 1964, Pollard 1968, Fuchs 1969, Neumann 1971, Borg 1973, Basedow et.al. 1976, Thiele 1977, Trittelvitz \& Topp 1980, Andersen 1982, Walker 1985, Niemelä et.al. 1985, 1986, 1987, Jarosik \& Hurka 1986, Nilsson 1987, Baguette 1987, Hance \& Gregorie-Wibo 1987, Tietze 1987, Dufrene 1987, Plaisier 1988, Niemelä 1988, Lester \& Morill 1989, Andersen et.al. 1990, Vogel \& Krost 1990, Luff 1990, Loreau 1992). There are, therefore, all reasons to assume that the largest species within a community are highly over-represented in pitfall traps.

The reason why large carabids often seem to be over-represented in pitfall traps relative to smaller species is probably that they have to move about more, both to find mates and more scattered food. Large carnivorous carabid species generally eat larger food items than smaller ones. Earthworms, slugs, snails and caterpillars, for example, form an important part of the diet of Carabus, Abax and large Pterostichus species whereas mites, small spiders, collemboles, aphids, insect eggs and smaller larvae and enchytraeids are essential food items of smaller species (Lindroth 1945, 1985-86, Dawson 1965, Thiele 1977, Hengeveld 1980, Andersen 1987). The abundance of the latter prey items is usually much higher than that of the former ones (Wallwork 1970, Marcuzzi 1979).

Since most field studies of carabids are based on catches in pitfall traps, it is concluded that our general insight into their community structure may be very biased.

According to Thiele (1977) "activity abundance"provides a good estimate of the role 
of a species in an ecosystem, since this not only depends on its frequency but also on its mobility, for example in catching prey. This means that larger species with low abundance but high activity may be equally, or more, important than smaller species with higher abundance, but lower activity. Energy flow (production of biomass + respiration) in a population provides the most reliable basis for determining the role of a population within its community (Odum 1971). In the present study the small species constitute at least about equally much in biomass per unit area as the larger species, whereas it partly was quite opposite in pitfall trap catches. Converted to energy flow, the difference between small and large species in quadrat samples would be larger since the metabolic rate per unit of body weight decreases with increasing size (Odum 1971). The results for quadrat samples are in accordance with Griffiths (1992) who found that small species are energetically as or more important in communities than large. Consequently, pitfall traps may give biased results regarding to the role of species in ecosystems.

Calculations of species diversity indices have been based on pitfall trap results (e.g. Jarosik \& Hurka 1986, Tietze 1987, Vansteenwegen 1987, Bauer 1989). Dennison \& Hodkinson (1984) found that pitfall trapping gave the highest estimates of the S component (number of species) of diversity, but gave a poor estimate of the $\mathrm{E}$ component, whereas the latter was best measured by flotation or pitfall trapping with enclosures. The first was confirmed by the present investigation whereas the values of $\mathrm{H}$ and $\mathrm{E}$ partly were higher in pitfall traps than in quadrat samples, partly vice-versa. More investigations obviously have to be done before drawing any general conclusions about the validity of using the ShannonWiener index based on pitfall trap catches.

It is concluded that the "open"pitfall trap method is inappropriate for studying the dominance ratio, the ecological role of species, and perhaps species diversity, within communities. There are also reasons to be careful regarding drawing conclusions about habitat selection of individual species and habitat overlap between species based on this method. In other contexts, however, the method is superior, e.g. in faunistic studies and in studies of diel activity pattern.
For species with sufficiently high density, e.g. Bembidion spp. Dyschirius spp. quadrat sampling seems to be a reliable method to determine absolute abundance (Andersen 1983a, present paper). For highly mobile species with low abundance, other methods have to be employed. Pitfall traps with fences covered by roofs may be one promising method to use in such cases (Desender \& Maelfait 1986, Garry 1993). In principle, however, this may be regarded as a special type of quadrat sampling.

Acknowledgements. I am greatful to A. Read, A. Nilssen and K. E. Erikstad for critically reading the manuscript.

\section{References}

Andersen, A. 1982: Carabidae and Staphylinidae (Col.) in swede and cauliflower fields in southern-eastern Norway. - Fauna Norv. (B) 29: 49-61.

Andersen, J. 1968: The effect of inundation and choice of hibernation sites of Coleoptera living on river banks. - Norsk Entomol. Tidsskr. 15: 115-133.

- 1970: Habitat choice and life history of Bembidiini (Col., Carabidae) on river banks in Central and Northern Norway, - Norsk Entomol. Tidsskr. 17:17-65.

- 1983a: The habitat distribution of species of the tribe Bembiini (Coleoptera, Carabidae) on banks and shores in northern Norway. - Notulae Entomol. 63:131-142.

- 1983b: The life cycles of the riparian species of Bembidion (Coleoptera, Carabidae) in northern Norway, - Notulae Entomol. 63:195-202.

- 1987: Resource partitioning and interspecific interactions among riparian Bembidion species (Coleoptera: Carabidae. - Entomol. Generalis 13:47-60.

Andersen, T., Ligaard, S., Pedersen, T. \& Søli, G. E. E. 1990: Pitfall catches of Carabidae and Staphylinidae (Coleoptera) in a temporary protected forest area on the Eidanger peninsula, Telemark, SE Norway. Fauna Norv. (B) 37:13-22.

Adis, J. 1979: Problems of interpreting arthropod sampling with pitfall traps. - Zool. Anz. 202:177-184.

Baars, M. A. 1979: Catches in pitfall traps in relation to mean densities of carabid beetles. - Oecologia (Berlin) $41: 25-46$.

Baguette, M. 1987: Spring distribution of carabid beetles in different plant communities of Belgian forests. Acta Phytopath. Entomol. Hung. 22:57-69.

Basedow, T., Borg, A., deClercq, R., Nijveldt, W. \& Scherney, F. 1976: Untersuchungen über das vorkommen der Laufkäfer (Col.: Carabidae) auf eurpäischen Getreidefeldern. - Entomophaga 21:59-72.

Basedow, T., Klinger, K., Froese, A. \& Yanes, G. 1988: Aufschwemmung mit Wasser zur Schnellbestimmung der Abundanz epigäischer Raubarthropoden auf 
Äckern. - Pedobiologia 32:317-322.

Bauer, L. J. 1989: Moorland beetle communities on limestone "habitat islands". I. Isolation, invasion and local species diversity in carabids and staphylinids. - $\mathrm{J}$. Anim. Ecol. 58:1077-1098.

Bengtson, S. - A. 1980: Species assemblages and coexistence of Faroe Island ground beetles (Coleoptera: Carabidae). - Entomol. Generalis 6:251-266.

Blackburn, T. M., Harvey, P. H. \& Pagel, M. D. 1990: Species number, population density and body size relationships in natural communities. - J. Anim. Ecol. 59:335-345

Bombosch, S. 1962: Untersuchungen über die Auswertbarkeit von Fallenfängen. - Zsch. Ang. Zool. 49:149-160.

Borg, A. 1973: Förekomst av carabider i en jordgubbsodling (Col. Carabidae). -- Entomol. Tidsskr. 94:56-58.

Briggs, J. B. 1960: A comparison of pitfall trapping and soil sampling in assessing populations of two species of ground beetles (Col.: Carabidae). - Annual Report of the East Malling Research Station for 1960:108-112.

Currie, D. J. 1993: What shape is the relationship between body size and population density? - Oikos 66:353358.

Davies, M. 1953: The contents of the crops of some British carabid beetles. - Entomol. Mon. Mag. 89:18-23.

Dawson, N. 1956: A comparative study of the ecology of eight species of fenland Carabidae (Coleoptera). - J. Anim. Ecol. 34:299-314.

DenBoer, P. J. 1980: Exclusion or coexistence and the taxonomic or ecological relationship between species. — Netherlands J. Zool. 30:278-306.

Dennison, D. F. \& Hodkinson, I. D. 1984: Structure of the predatory beetle community in a woodland soil ecosystem. IV. Population densities and community composition. - Pedobiologia 26:157-170.

Desender, K. \& Maelfait, J. P. 1986: Pitfall trapping within enclosures: a method for estimating the relationship between the abundance of coexisting carabid species (Coleoptera: Carabidae). — Holarctic Ecol. 9:245250.

Dufrene, M. 1987: Distribution of carabid beetles in a Belgian peat bog: preliminary results. - Acta Phytopath. Entomol. Hung. 22:349-355.

Erikstad, K. E. 1989: The diel activity of carabid beetles (Coleoptera) north of the arctic circle, with particular reference to Patrobus assimilis Chaud. and Notiophilus aquaticus L. - Polar Biol. 9:319-323.

Erikstad, K. E., Byrkjedal, I. \& Kålås, J. A. 1989: Resource partitioning among seven species on Hardangervidda, Southern Norway. - Ann. Zool. Fennici. 26:113-120.

Forsythe, T. G. 1982: Feeding mechanisms of certain ground beetles (Coleoptera: Carabidae). — Coleopterists' Bull. 36:26-73.

Frank, J. H. 1971: Carabidae (Coleoptera) of an arable field in Central Alberta. - Questions Entomologicae $7: 237-252$.
Fuchs, G. 1969: Die ökologische Bedeutung der Wallhecken in der Agrarlandschaft Nordwestdeutschlands, am Beispiel der Käfer. - Pedobiologia 9:432-458.

Garry, C. E. 1993: Ground beetles (Coleoptera: Carabidae) of paleoenvironmental significance of the forest-tundra and open woodland of Northern Manitoba, Canada. - Coleopterists' Bull. 47:89-106.

Greenslade, P. J. M. 1963: The habitats of some Carabidae (Coleoptera). — Entomol. Mon. Mag. 99:129-132.

- 1964a: Pitfall trapping as a method for studying populations of Carabidae (Coleoptera). - J. Anim. Ecol. 33:301-310.

- 1964b: The distribution, dispersal and size of a population of Nebria brevicollis (F.) with comparative studies on three other Carabidae, - J. Anim. Ecol, 33:311-333.

- 1965: On the ecology of some British carabid beetles with special reference to life histories. - Trans. Soc. British Entomol. 16:149-179.

Griffiths, D. 1992: Size, abundance, and energy use in communities. - J. Anim. Ecol. 61:307-315.

Grüm, L. 1971: Spatial differentiation of the Carabus L (Carabidae, Coleoptera) mobility. — Ekol. Polska 19:1-34.

Grutke, H. \& Weigmann, G. 1990: Ecological studies on the carabid fauna (Coleoptera) of a ruderal ecosystem in Berlin. - In Stork, N. (ed.): The role of ground beetles in ecological and environmental studies. Intercept Ltd; Andover, Hampshire, pp. 181-189.

Halsall, N. B. \& Wratten, S. D. 1988: The efficiency of pitfall trapping for polyphagous predatory Carabidae. - Ecol. Entomol. 13:293-299.

Hance, T. \& Gregoire-Wibo, C. 1987: Effect of agricultural practices on carabid populations. - Acta Phytopath. Entomol. Hung. 22:147-160.

Hejkaal, J. 1990: Carabids/Coleoptera, Carabidae of the peat bog Soos in W-Bohemia: A faunistical and ecological study. - Folia Musei Rerum Naturalium Bohemiae Occidentalis. Plzen Zoologica 32:1-55.

Hengeveld, R. 1980: Polyphagy, oligophagy and food specialization in ground beetles (Coleoptera, Carabidae). - Netherlands J. Zool. 30:564-584.

Heydemann, B. 1962: Der Einfluss des Deichbaus an der Nordsee auf larven und Imagines von Carabiden und Staphyliniden. - Berichte über die Wanderversammlung Deutscher Entomologen 9:237-274.

- 1964: Die Carabiden der kulturbiotope von Binnenland und Nordseeküste- ein ökologischer Vergleich (Coleopt., Carabidae). —Zool. Anz. 172:49-86.

Holopainen, J. K. 1983: Carabid beetles (Col. Carabidae) associated with cruciferous crops in organic and conventional farms in Central Finland. - Savonia 6:1927.

- 1990: Influence of ethylene glycol on the numbers of carabids and other soil arthropods caught in pitfall traps. - In: Stork, N. (ed.): The role of ground beetles in ecological and environmental studies. Intercept Ltd, Andover, Hampshire, pp. 339-341.

Jarosik, V. \& Hurka, K. 1986: Die Coleopterfauna des 
Rapsfelds. - Vest. Cs. Spolec. Zool. 50:192-212.

Johnson, N. E. \& Cameron, R. S. 1969: Phytophagous ground beetles. - Ann. Entomol. Soc. America 62:909-914.

Kegel, B. 1990: Diurnal activity of carabid beetles living on arable land. - In: Stork, N. (ed.): The role of ground beetles in ecological and environmental studies. Intercept Ltd, Andover, Hampshire, pp. 65-76.

Kuschka, V., Lehmann, G. \& Meyer, U. 1987: Zur Arbeit mit Bodenfallen. - Beitr. Entomol. 37:3-27.

Lester, D. G. \& Morill, W. L. 1989: Acivity density of ground beetles (Coleoptera: Carabidae) in alfalfa and sainfoin. - J. Agric. Entomol. 6:71-76.

Lindroth, C. H. 1945: Die fennoskandischen Carabidae I. — Göteborgs Kgl. Vet. Vitterh. Samh. Handl., (B) 4: 1-709.

- 1949: Die fennoskandischen Carabidae III. — Göteborgs Kgl. Vet. Vitterh. Samh. Handl. (B) 4: 1-911.

- 1985-86: The Carabidae (Coleoptera) of Fennoscandia and Denmark. - Fauna Entomol. Scand. 15:1-497.

Loreau, M. 1992: Species abundance patterns and the structure of ground-beetle communities. - Ann. Zool. Fennici 28:49-56.

Luff, M. L. 1967: Some effects of formalin on the numbers of Coleoptera caught in pitfall traps. - Entomol. Mon. Mag. 104:115-116.

- 1975: Some features influencing the efficiency of pitfall traps. - Oecologia (Berlin) 19:345-357.

- 1978: Diel activity patterns of some field Carabidae. - Ecol. Entomol. 3: 53-62.

- 1982: Population dynamics of Carabidae. - Ann. Appl. Biol. 101:164-170.

- 1990: Spatial and temporal stability of Carabid communities in a grass/arable mosaic. - In: Stork, N. (ed.): The role of ground beetles in ecological and environmental studies. Intercept Ltd. Andover, Hampshire, pp. 191-200.

Lücke, E. 1960: Die epigäsche Fauna auf Zuckerrübenfeldern unterschiedlicher Bodenverhältnisse im Göttinger Raum. —Zschr. Angew. Zool. 47:43-90.

Marcuzzi, G. 1979: European Ecosystems. - Biogeographica 15. W. Junk, The Hague, 779 pp.

Morse, D. R., Stork, N. E. \& Lawton, J. H. 1988: Species number, species abundance and body length relationships of arboreal beetles in Bornean lowland rain forest trees. - Ecol. Entomol. 13:25-37.

Morill, W. L., Lester, G. D. \& Wrona, A. E. 1990: Factors affecting efficacy of pitfall traps for beetles (Coleoptera: Carabidae and Tenebrionidae). - J. Entomol. Sci. 25:284-293.

Mossakowski, D. \& Stier, J. 1983: Vergleichende Untersuchungen zur Laufge-schwindigkeit der Carabiden. - In Brandmayr, P., DenBoer, P. J. \& Weber, F. (eds): Ecology of carabids: the synthesis of field study and laboratory experiment. Report of the fourth meeting of European Carabidologists, pp. 19-33.

Murdoch, W. W. 1967: Life history patterns of some British Carabidae(Coleoptera) and their ecological signifi- cance. - Oikos 18:25-32.

Neumann, U. 1971: Die Sukzession der Bodenfauna (Carabidae (Coleoptera), Diplopoda und Isopoda) in den forstlich rekultivierten Gebieten des rheinischen Braunkohlenreviers. - Pedobiologia 11:193-226.

Niemelä, J, 1988: Habitat occupancy of carabid beetles on small islands and the adjacent Aland mainland, SW Finland. - Ann. Zool. Fennici. 25:121-131.

Niemelä, J., Ranta, E. \& Haila, Y. 1985: Carabid beetles in lush forest patches on the Åland Islands, south-west Finland: an island-mainland comparison. - J. Biogeogr. 12:109-120.

Niemelä, J., Haila, Y. \& Ranta, E. 1986: Spatial heterogenity of carabid beetle dispersion in uniform forests on the Åland Islands, SW Finland. - Ann. Zool. Fennici. 23:289-296.

Niemelä, J., Haila, Y., Ranta, E., Tiainen, J., Vepsäläinen, K. \& As, S. 1987: Distribution of carabid beetles in four boreal archipelagoes. - Ann. Zool. Fennici. 24:89-100.

Niemelä, J., Halme, E. \& Haila, Y. 1990: Balancing sampling effort in pitfall trapping of carabid beetles. Entomol. Fennica I:233-238.

Nilsson, I. N. 1987: Carabid beetles in oak forests in southern Sweden. - Entomol. Meddr. 55:171-174.

Odum, E. P. 1971: Fundamentals of Ecology. - Saunders, Philadelphia, 574 pp.

Ottesen, P. S. 1985: Diel activity patterns of South Scandinavian high mountain ground beetles (Coleoptera, Carabidae), - Holarct. Ecol. 8:191-203.

Pianka, E. 1975: Niche relations of desert lizards. - In Cody, M. L. \& Diamond, J. M. (eds.): Ecology and evolution of communities. Harvard University Press, Cambridge, pp. 292-314.

Plaisier, F. 1988: Zur Besiedlung junger Düneninseln durch Lauf und Aaskäfer (Coleoptera: Carabidae, Silphidae). - Drosera 88:69-82.

Pollard, E. 1968: Hedges III. The effect of removal of the bottom flora of a hawthorn hedgerow on the Carabidae of the hedge bottom. - J. Appl. Ecol. 5:125-139.

Refseth, D. 1980: Differences in seasonal activity pattern and breeding time of Patrobus atrorufus (Carabidae) in central Norway. - Holarctic Ecol. 3:87-90.

- 1986: Phenological adaptation in Patrobus atrorufus and $P$. assimilis (Col., Carabidae). - Fauna Nory. (B) 33: $57-63$.

- 1988: Annual patterns of activity, reproduction and development in some norwegian Carabidae (Col.). Fauna Norv. (B) 35: 21-30.

Scherney, F. 1960: Beiträge zur Biologie und ökonomischen Bedeutung räuberisch lebender Käferarten. - Ztschr. Ang. Ent. 47:231-255.

Schjötz-Christensen, B. 1957: The beetle fauna of the Corynephoretum in the ground of the Mols Laboratory. - Natura Jutlandica 6-7:1-120.

- 1965: Biology and population studies of Carabidae of the Corynephoretum, - Natura Jutlandica 11:1-173.

Sekulic, R., Camprag, D. Keresi, T. \& Talosi, B. 1987: 
Fluctuations of Carabid population density in winter wheat fields in the region of Backa, Norteastern Yugoslavia (1961-1985). - Acta Phytoph. Entomol. Hung. 22:265-271.

Siegel, S. 1956: Nonparametric statistics for the behavioral sciences. - MacGraw-Hill Book Company, Inc. Kögakusha, Tokyo, 574 pp.

Spence, R. J. \& Niemelä, J. K. 1994: Sampling carabid assemblages with pitfall traps: the madness and the method. - Can. Entomol. 126:881-894.

Thiele, H. - U. 1977: Carabid beetles in their environments. A study on habitat selection by adaptions in physiology and behaviour. - Zoophysiology and Ecology 10, Springer, Berlin, 379 pp.

Thingstad and, P. G. 1987: Pitfall trapping of the carabid fauna in alpine and subalpine habitats at Saltfjellet, North Norway. - Fauna Norv. (B) 34:105-116.

Tietze, F. 1987: Changes in the structure of carabid beetle taxocenoses in grassland affected by intensified management and industrial air pollution. - Acta Phytoph. Entomol. Hung. 22:305-319.

Tischler, W. 1958: Synökologische Untersuchungen an der Fauna der Felder und Feldgehölze (Ein Beitrag zur Ökologie der Kulturlandschaft). - Ztschr. Morph. Ökol. Tiere 47:54-114.

Trittelviz, W. \& Topp, W. 1980: Verteilung und Ausbreitung der epigäischen Arthropoden in der Agrarlandschaft. I. Carabidae. - Anz. Schädlingskde Planzenschutz, Umveltschutz 53:17-20.

Vansteenvegen, C. 1987: Distribution of carabid beetles in natural areas within an agricultural region. - Acta Phytoph. Entomol. Hung. 22: 439-448.

Vogel, J. \& Krost, P. 1990: The carabid fauna of pedologically and floristically different forest biotopes in Schleswig-Holstein, West Germany. - FaunistischÖkologische Mitteilungen 6:87-94.

Walker, M. A. 1985: A pitfall trap study on Carabidae and Staphylinidae (Col.) in County Durham. - Entomol. Mon. Mag. 121: 9-18.

Wallwork, J. A. 1970: Ecology of Soil Animals. McGraw-Hill, London, 283 pp.

Zetto Brandmayr, T. \& Brandmayr, P. 1978: Discussion on the biology of a very interesting carabid, Tetraplatypus ganglbaueri - Cordulia 4:156-159. 


\section{Appendices}

Appendix 1. Catches of Carabid beetles in pitfall traps $(P)$ and quadrat samples $(Q)$ in microhabiatat $2 \mathrm{a}$ at locality 1 . Information about reproductive type and diel activity pattern is from Andersen (1970, 1983b), Thiele (1977), Luff (1978), Lindroth (1985-86), Ottesen (1985), Desender \& Maelfait (1986), Refseth $(1986,1988)$ and own unpublished data.

\begin{tabular}{|c|c|c|c|c|}
\hline \multirow[b]{2}{*}{ Species } & Reproductive & \multirow{2}{*}{$\begin{array}{l}\text { e Diel } \\
\text { activity }\end{array}$} & \multicolumn{2}{|c|}{ Number of specimens In } \\
\hline & Type & & $\mathrm{P}$ & $Q$ \\
\hline Nebria rufescens (Strøm) & II & $\mathrm{N}$ & 203 & 1 \\
\hline Bembidion lunatum (Duftschmid) & II & D & 44 & 14 \\
\hline Patrobus atrorufus (Strøm) & II & $\mathrm{N}$ & 40 & 2 \\
\hline Trechus secalis (Paykull) & II & $\mathrm{N}$ & 30 & 10 \\
\hline Calathus erratus (Sahlberg) & II & $\mathrm{N}$ & 4 & 0 \\
\hline Clivina fossor (L.) & 1 & D & 2 & 0 \\
\hline Loricera pilicornis (Fabricius) & 1 & D & 1 & 0 \\
\hline
\end{tabular}

I: Spring breeder; II autumn breeder; D: diurnal ( $>30 \%$ diurnal activity); N: nocturnal ( $<30 \%$ diurnal activity).

Appendix 2. Catches of carabid beetles in pitfall traps $(P)$ and quadrat samples $(Q)$ in microhabitat 3 a at locality 2 , July 1990 . For further explanations see Appendix 1.

\begin{tabular}{|c|c|c|c|c|}
\hline \multirow[t]{2}{*}{ Reproducti } & & \multirow[t]{2}{*}{$\begin{array}{r}\text { Diel } \\
\text { activity }\end{array}$} & \multicolumn{2}{|r|}{$\begin{array}{l}\text { Number of } \\
\text { specimens in: }\end{array}$} \\
\hline & & & $\mathrm{P}$ & $Q$ \\
\hline Bembidion schuppelii Dejean & I & $\mathrm{D}$ & 17 & 21 \\
\hline Agonum fuliginosum (Panzer) & I & $\mathrm{N}^{*}$ & 11 & \\
\hline Bembidion bipunctatum (L.) & I & D & 6 & 1 \\
\hline Clivina fossor & 1 & D & 6 & 1 \\
\hline Dyschirius septentrionum Munster & 1 & D & 6 & 2 \\
\hline Elaphrus cupreus Duftschmid & 1 & D & 4 & 2 \\
\hline E. riparius (L.) & 1 & D & 3 & \\
\hline Loricera pilicornis & I & D & 3 & \\
\hline Bembidion bruxellense Wesmael & I & $\mathrm{D}$ & 3 & 2 \\
\hline Pelophila borealis (Paykull) & I & $\mathrm{N}^{*}$ & 2 & \\
\hline Patrobus septentrionis Dejean & II & $\mathrm{N}^{*}$ & 1 & \\
\hline P. assimilis Chaudoir & II & $\mathrm{N}^{*}$ & 1 & 1 \\
\hline Calathus melanocephalus (L.) & II & $\mathrm{N}^{*}$ & 1 & \\
\hline Dyschirius globosus (Herbst) & I & $\mathrm{D}$ & & 4 \\
\hline
\end{tabular}

* At least at lower latitudes, but vide Erikstad (1989) 
Appendix 3. Catches from pitfall traps $(P)$ and quadrat sampling $(Q)$ in various microhabitats on locality 2, July 1988 . The table gives total number of specimens collected of each species and $95 \%$ confidence limits (in brackets) of the mean per trap and week or quadrat of the more abundant species. For further explanation see Appendix 1.

\begin{tabular}{|c|c|c|c|c|c|c|c|c|}
\hline \multirow[b]{2}{*}{ Species } & \multicolumn{3}{|r|}{$3 a$} & \multicolumn{2}{|c|}{ MICROHABITAT } & \multicolumn{2}{|c|}{ 4a Carex } & $4 b$ \\
\hline & & $P$ & $Q$ & $\mathrm{P}$ & $\mathrm{Q}$ & $P$ & Q & $\mathrm{P}$ \\
\hline Pelophila borealis & $N$ & $11(0-2.2)$ & & 3 & $339(12.8-48.8)$ & & $46(1.4-7.5)$ & \\
\hline Bembidion schuppelii & D & $9(0-1.6)$ & $15(0.3-2.2)$ & $27(1.6-2.9)$ & $66(2.5-4.1)$ & $2(0-0.5)$ & $15(0.4-1.4)$ & $11(0.7-1.7) 2(0-0.5)$ \\
\hline B. bipunctatum & D & 2 & & $36(0.3-3.7)$ & $4(0-0.4)$ & $6(0-0.8)$ & $111(5.3-15.9)$ & $20(1.1-2.9)$ \\
\hline Elaphrus cupreus & D1 & $1(0.1-1.9)$ & & $8(0.7-2.2)$ & 2 & 2 & & \\
\hline E. riparus & D & & $9(0-1.4)$ & & 1 & & & \\
\hline Lorocera pilicornis & $\mathrm{D}$ & 1 & & & 3 & & & \\
\hline Clivina fossor & $\mathrm{D}$ & 3 & & 2 & & & $20(0.9-3.5)$ & \\
\hline Patrobus assimilis & $N$ & 7 & & 1 & & & & \\
\hline P. septentrionis & $N$ & 2 & & & 1 & & & \\
\hline B. bruxellense & D & & & 1 & 1 & & & \\
\hline Dyschirius septentrionis & $\mathrm{D}$ & 3 & 1 & & 1 & & & \\
\hline Calathus melanocephalus & $\mathrm{N}$ & 7 & 1 & & & & & 1 \\
\hline Agonom fuliginosum & $\mathrm{N}$ & & & & 1 & $9(0-1,4)$ & 1 & 2 \\
\hline
\end{tabular}

Appendix 4. Results of dissection of females of spring breeding species collected at locality 2 between 9.7 and 16.7. 1988.

\begin{tabular}{lrr}
\hline Species & $\begin{array}{c}\text { Ovaries } \\
\text { Mature }\end{array}$ & Spent \\
\hline Pelophila borealis & 26 & 11 \\
Elaphrus cupreus & 12 & 4 \\
Clivina fossor & 2 & 1 \\
Dyschirius globosus & 1 & - \\
D. septentrionis & 3 & 1 \\
Bembidion bipunctatum & 25 & 8 \\
B. schuppelii & 13 & 5 \\
Agonum fuliginosum & 2 & - \\
\hline
\end{tabular}

